\title{
The Effects of Openness on Managerial Innovation in Cameroonian Companies
}

\author{
Joel Stephan Tagne, University of Ngaoundere, Cameroon \\ Paul Ningaye, University of Dschang, Cameroon \\ Georges Kobou, University of Yaounde II, Cameroon
}

\begin{abstract}
The objective of this study was to analyze the effects of openness on the adoption of managerial innovation by Cameroonian companies, as well as comparing the share of managerial innovation resulting from inter-organizational networks of the same group and of different groups. Noting a lack of such a study on Cameroon, this study used data from the Centre de Recherche en Economie et Gestion (CEREG) to achieve the objective. Using a binary probit model and a recursive bivariate probit model, the authors found that, first, a company that collaborates with other companies has an increased probability of 0.37 of adopting new managerial practices, compared to another company that does not collaborate. Second, a company belonging to a group that collaborates with companies of a different group has an increased probability of 0.30 of adopting new managerial practices, compared to a company that only collaborates with companies of the group to which she belongs. Business leaders should cooperate with all market players.
\end{abstract}

\section{KEYWORDS}

Cameroon, Coercive Isomorphism, Company, Force of Selection, Managerial Innovation, Mimicry, Openness

\section{INTRODUCTION}

Innovation is seen as a major driving force for economic development (Fagerberg, 1987; Wang \& Chan, 2013) and even for sustainable development (Shen, Siraj, Jiang, Zhu \& Li, 2020). Many researchers present innovation as the introduction of a new product or process into operations, but the improvement of an existing product or process can also be considered as an innovation (Ozgen, Nijkamp \& Poot, 2013). However, according to Le Roy et al. (2013), this definition is more suitable for technological innovations in research and development laboratories. Other authors have focused their attention on non-technological innovations such as administrative and managerial innovations. Evan (1966) considers an administrative innovation to be an innovative idea relating to the recruitment of staff, the allocation of resources, the definition of tasks, the management method or the development of staff. On the other hand, Hamel (2006) presents managerial innovation as a new organization, a new administrative system, new managerial practices or new techniques that can create value for the organization adopting them. It refers to human capital, leadership and performance (Ziadlou, 2020). Thus, a company is considered to have innovated at the managerial level if it has adopted new management practices or methods to improve its overall performance (La Roy, Robert \& Giuliani, 2013; Montalvan-Burbano, Plaza-Ubeda, Perez-Valls \& Sabando-Vera, 2019). 
By using the data from the "Centre de Recherche en Economie et Gestion (CEREG)" of the University of Yaoundé II, 51.79\% of Cameroonian companies declare that they have innovated at the managerial level. To further enhance this level of innovation, many determinants have been identified using two approaches; the first approach considers innovation to be technological and is determined by enormous investment in research and development, the qualification of the workforce and the spread of new information and communication technologies (Biatour \& Kegels, 2008). The second approach considers non-technological innovation, which is put into practice by staff training, customer/supplier relations and, to a lesser extent, research and development (Mongo, 2013). These different determinants are referred to as internal determinants of the innovation process.

Faced with an increasingly dynamic and complex market, many companies are turning to the open innovation model characterized by collaborations and partnerships (Cheng, Lyu, Su \& Han, 2019; Dekkers, Koukou, Mitchell \& Sinclair, 2019). Thus, a company may have other external resources that can strengthen its innovation potential (Stanisławski \& Lisowska, 2015). In such a case we speak of open innovation (Huang \& Rice, 2012). This type of innovation combines both internal and external ideas from the company (Bogers, Chesbrough \& Moedas, 2018). By collaborating with other actors, a company is likely to multiply its sources of innovation to which it has access. These external actors are customers, suppliers, universities, research laboratories, public authorities and competitors. Thus, by collaborating with these external actors, firms can access external knowledge and ideas that complement and enhance their knowledge bases, thus effectively accelerating innovation (Terjesen \& Patel, 2017; Zobel, Lokshin \& Hagedoorn, 2017; Di Nauta, Merola, Caputo \& Evangelista, 2018; Sun \& Cao, 2018; Cheng, Lyu, Su \& Han, 2019).

On a theoretical level, researchers who found that openness could have an effect on managerial innovation based themselves on the institutional theory, that the decision to adopt new managerial practices depends on the institutional environment in which the company operates (Dubouloz \& Bocquet, 2013). Though all of them have the institutional theory as their yardstick, their ideas are sometimes divergent. However, some consider that some companies adopt new managerial practices because they are victims of many pressures from different external partners (Abrahamson, 1991; Dimaggio \& Powell, 1983). This approach is called "force selection perspective" or "coercive isomorphism".

However, managerial innovation is not only determined by external pressures (Damanpour \& Aravind, 2012). Therefore, to others, firms may decide to emulate some of their partners because they seem to cope more effectively or easily with market uncertainty or economic difficulties (Teece, 1980; Dimaggio \& Powell, 1983; Abrahamson, 1991). However, although the idea of mimicry and pressure have been strongly presented in the literature, another approach has been also implemented. To others, a company's ability to use external knowledge rationally can affect its ability to adopt managerial innovation (Cohen \& Levinthal, 1990; Chesbrough, 2006; Mol \& Birkinshaw, 2009). These different theoretical studies have been confirmed in many empirical studies (Laursen \& Salter, 2006; Dubouloz \& Bocquet, 2013; Ganter \& Hecker, 2013; Radnejad \& Vredenburg, 2017; Bogers, Chesbrough \& Moedas, 2018; Damanpour, Sanchez-Henrique \& Chui, 2018; Bocquet \& Dubouloz, 2020).

However, these different studies were mainly carried out in the northern countries characterized by the predominance of large companies, in disregards of the specificity of companies in Sub-Saharan Africa and Cameroon in particular. Thus, to the best of our knowledge, no study has been carried out using Cameroonian data that focuses on this issue. Moreover, even if some previous studies have referred to the intensity of openness shown by the multiplication of partners, this study will also focus on the intensity of openness but shown here by collaboration between firms in the same group and collaboration between firms in different groups. Indeed, a group is a set of companies owned and managed directly or indirectly by a parent company. According to Ma et al. (2006), the affiliation of a company to a group facilitates its performance. However, the authors believe that a company that collaborates only with organizations of the same group may not achieve the same level of innovation performance as a company that collaborates with at least one organization in another group. However, 
the following question still needs to be asked: what are the effects of openness on the introduction of new management practices in Cameroonian companies?

The objective of this research is to analyze the effect of openness on the adoption of managerial innovation by Cameroonian companies, as well as comparing the share of managerial innovation resulting from inter-organizational networks of the same group and of different groups.

The remaining part of this study is organized as thus: the first part presents the literature review, the second presents the methodology and finally third discusses the different results.

\section{LITERATURE REVIEW}

Whether from Abrahamson's (1991) force of selection perspective, Dimaggio and Powell's (1983) coercive isomorphism, Dimaggio and Powell's (1983) mimicry perspective, or even Cohen and Levinthal's (1990) internal absorption capacity mechanisms perspective, very few authors have focused on the empirical verification of managerial innovation as compared to other types of innovation (Kostopoulos, Papalexandris, Papachroni \& Ioannou 2011; Damanpour, Sanchez-Henrique \& Chui, 2018). Dubouloz (2012), for example, through a case study on data on French manufacturing companies, finds that some customers can strongly encourage their subcontractors to adopt new organizational practices on quality standards. In this way, they can propose best practices that have already been tested in other companies. Other authors, such as Pfeffer and Salancik (1978) and Frambach and Schillewaert (2002) show that suppliers can also encourage companies to adopt new managerial practices through persuasive marketing practices and control of dispersed resources. To Dubouloz and Bocquet (2013), companies that collaborate with partners that have already adopted organizational innovation can imitate such partners, which will reduce the level of uncertainty surrounding that type of innovation and subsequently encourage these companies to adopt it as well. However, none of these previous empirical studies compares the imitation approach with the external pressure approach (Bocquet \& Dubouloz, 2020). Thus, using French data, these latter authors find that managerial innovation is influenced both by external research strategies, by coercive pressures and by a quest for legitimacy.

The adoption of organizational innovation requires that a company accumulate knowledge (Laursen \& Salter, 2006; Mol \& Birkinshaw, 2009). Consequently, a variety of potential sources of knowledge positively influences a company's ability to generate managerial innovations (Fey \& Birkinshaw, 2005; Borgatti \& Cross, 2003). In this light, Mol and Birkinshaw (2009), using data on UK companies find that knowledge from both the market (customers, suppliers, competitors, consultants) and other professional sources (professional associations) promotes the adoption of managerial innovation. Ganter and Hecker (2013) also find the same results with data on German companies. Similarly, Teece (1980) finds that companies that acquire knowledge from other companies can reduce the uncertainties and information asymmetries required for managerial innovation.

However, making value out of external knowledge is not automatic, it depends on the company's absorption capacity (Clausen, 2013; Huggins, Prokop \& Thompson, 2019). While firms with small amounts of resources and low absorptive capacity will tend to continue collaborating at the local level, those with much resources and higher absorptive capacity are likely to be more connected to interregional networks (Fantino, Mori \& Scalise, 2015; D’Ambrosio, Gabriele, Schiavone \& Villasalero, 2017; Johnston \& Huggins, 2017; Rojas, Solis \& Zhu, 2018). Thus, the higher the degree of absorption capacity of a company, the more it benefits from external knowledge flows (Escribano, Fosfuri \& Tribó, 2009). The results of these authors show that industrial companies that have developed internal mechanisms and routines that recognize the value of knowledge from external actors are companies that highly adopt organizational innovations.

Other authors have analyzed managerial innovation by distinguishing the effects according to firm size. While openness therefore positively influences both marketing innovation, and process 
innovation and organizational innovation, this effect is greater in small firms than in medium-sized firms (Hinteregger, Durst, Temel \& Yesilay, 2019).

The following $\mathrm{H} 1$ hypothesis can be formulated based on these arguments:

H1: a company's collaboration with external partners significantly facilitates the adoption of new managerial practices.

Some authors have focused their study more on the intensity of openness. For example, Tang et al. (2019) use survey data from 112 Chinese manufacturing companies and find that the number of external collaborators is positively correlated with the company's innovation. Other studies show that companies open to external sources do indeed benefit from additional central knowledge for managerial innovation activities, but may encounter difficulties when these external sources become too numerous (Laursen \& Salter, 2006; Dubouloz \& Bocquet, 2013). These authors show that the variety of external sources of knowledge encourages the adoption of new organizational practices, up to a certain threshold beyond which its effect becomes negative. This means that when a company has relationships with other companies, it can enhance its innovation potential, but as the number of links increases, a company can reach a level of saturation where the innovation benefits from external links are maximized (Koput, 1997). Beyond this level, the addition of another partner will result in a decrease in the company's innovation performance as a result of the difficulties in managing and monitoring these relationships (Audretsch \& Feldman, 1996; Laursen \& Salter, 2006; Sieg, Wallin \& Von Krogh, 2007; Ghisetti, 2018).

However, these previous studies are interested in the intensity of openness in terms of multiplication of partners without tarnishing the type or nature of the partnership or partner. However, other authors talk rather in terms of the extent and relevance of external sources. For example, D'Ambrosio et al. (2017) find that a more diversified research strategy results in significant innovation gains, however, the multiplication of partners has always a positive but weak effect. Similarly, Tether (2002) argues that the knowledge developed by some of the company's partners is less likely to be applicable in the short term and that they are often slow to respond and may not meet the needs of some companies. For example, researchers in research centers and universities most often focus on academic performance and generally disregard commercial results (Dasgupa \& David, 1994). Based on this last idea and considering that companies of the same group pursue the same objective, the following hypothesis, $\mathrm{H} 2$ can be formulated:

$\mathrm{H} 2$ : Collaboration between companies in the same group easily leads to the adoption of new managerial practices as compared to collaboration between companies in different groups.

\section{METHODOLOGY}

This study is based on secondary data from a survey financed by the International Development Research Centre (IDRC) as part of the analysis of the determinants of business performance in Frenchspeaking Sub-Saharan Africa. This survey was conducted in 2014 in Côte d'Ivoire, Cameroon and Senegal. The part relating to Cameroon was carried out by the Centre de Recherche en Economie et Gestion (CEREG) of the University of Yaoundé II where 643 companies from three main cities of the country were surveyed. In this sample, $11.41 \%$ of companies were surveyed in the city of Bafoussam, $62.97 \%$ in the city of Douala and $25.63 \%$ in the city of Yaoundé. A questionnaire was administered to a correspondent of the company who could be either the general manager of the company, the deputy general manager, the accountant or the administrative and financial director or any other employee. This questionnaire made it possible to collect information on the company's identity and location, its capacity to innovate, its environmental policy, its production, its turnover, 
its added value, its business environment, information and communication technologies and finally on the characteristics of the workforce and employment.

\section{Statistical Analysis of Variables}

Managerial innovation has been measured by: first, the company's ability to introduce new ways of operating in the organization of procedures; second, the company's ability to introduce new methods of work organization and decision-making; third, the company's ability to introduce new methods of organizing external relations with other companies or bodies. If a company has adopted at least one of the three behaviors, it will be considered to have innovated at the managerial level. Thus, $51.79 \%$ of the companies in our sample state that they introduced a managerial innovation during the three years preceding the survey.

The openness was in turn measured at two levels. At the first level, the authors considered that a company is open to its environment if it has cooperated with other companies or organizations (other companies in the same group, suppliers, customers, companies in the same sector, companies in other sectors, consultants, commercial laboratories, higher education institutions, other research and development organizations) for innovation activities. Thus, when reading Table 1, it can be seen that few companies (18.59\%) report having cooperated with other companies or organizations. The proportion of companies that have cooperated with other organizations and innovated in management is higher than that of companies that have not innovated $(0.2909>0.0741)$.

At the second level, the authors have instead measured the degree of openness by considering that a company that cooperates only with companies or bodies in the same group is less open than a company that cooperates with at least one company from a different group. In the sample of companies that report having cooperated in the market, $25.21 \%$ report having cooperated only with the organizations in their group compared to $74.79 \%$ who report having cooperated either only with companies in other groups or with companies in the same group and those in other groups at the same time. It can also be seen that the proportion of companies that have cooperated only with other companies in the same group and introduced a managerial innovation is higher than those that have not introduced any managerial innovation $(0.3020>0.0434)$.

\section{Econometric Models}

The model used is based on previous theoretical developments. This is in order to minimize the problems of endogeneity bias. The authors realize by referring to their problem that the company $i$ could make a decision between adopting a managerial innovation (I) or not $(\mathrm{N})$. Consider $U_{i j}$ the maximum possible utility of the company $i$ when it chooses one of the two (managerial innovation or not) alternatives $\mathrm{j}$, this function is decomposed into a deterministic component and a stochastic component such that:

$U_{i j}=X_{i} \beta_{j}+\varepsilon_{i j}$

With $X_{i}$ the vector of observable characteristics, $\beta_{j}$ the vector of the company's parameters when choosing the option $j$ and $\varepsilon_{i j}$ the error term. The utility of this choice is not observable, what is observable is the choice $Y_{i}$ and is such that:

$y_{1, i}=\left\{\begin{array}{l}1 \text { if the entreprise innovates at the manageriallevel } \\ 0 \text { otherwise }\end{array}\right.$ 
Table 1. Statistical analysis (Proportion and standard deviation) of variables

\begin{tabular}{|c|c|c|c|c|}
\hline \multirow[t]{3}{*}{ Variables } & \multirow[t]{3}{*}{ Description of the variables } & \multicolumn{3}{|c|}{ Proportion (standard deviation) } \\
\hline & & \multirow[t]{2}{*}{ All together } & \multicolumn{2}{|c|}{ Managerial innovation } \\
\hline & & & $\begin{array}{l}1 \text { if innovation } \\
\text { management }\end{array}$ & 0 otherwise \\
\hline Openness & $\begin{array}{l}1 \text { if cooperation with other } \\
\text { organizations } \\
0 \text { otherwise }\end{array}$ & $\begin{array}{l}0,1859(0,0153) \\
0,8141(0,0153)\end{array}$ & $\begin{array}{l}0,2909(0,0250) \\
0,7090(0,0250)\end{array}$ & $\begin{array}{l}0,0741(0,0149) \\
0,9258(0,0149)\end{array}$ \\
\hline $\begin{array}{l}\text { Openness } \\
\text { intensity }\end{array}$ & $\begin{array}{l}1 \text { if cooperating only with other } \\
\text { organizations in the same group } \\
0 \text { otherwise }\end{array}$ & $\begin{array}{l}0,2521(0,0399) \\
0,7479(0,0399)\end{array}$ & $\begin{array}{l}0,3020(0,0471) \\
0,6979(0,0471)\end{array}$ & $\begin{array}{l}0,0434(0,0434) \\
0,9565(0,0434)\end{array}$ \\
\hline $\begin{array}{l}\text { Absorption } \\
\text { capacity }\end{array}$ & $\begin{array}{l}1 \text { if the company has a high } \\
\text { absorption capacity } \\
0 \text { otherwise }\end{array}$ & $\begin{array}{l}0,5516(0,0203) \\
0,4483(0,0203)\end{array}$ & $\begin{array}{l}0,5032(0,0286) \\
0,4967(0,0286)\end{array}$ & $\begin{array}{l}0,6020(0,0285) \\
0,3979(0,0285)\end{array}$ \\
\hline $\begin{array}{l}\text { Size of the } \\
\text { company }\end{array}$ & $\begin{array}{c}0 \text { if very small company } \\
1 \text { if small and medium-sized } \\
\text { company } \\
2 \text { if large company }\end{array}$ & $\begin{array}{l}0,6109(0,0192) \\
0,1921(0,0155) \\
0,1968(0,0157)\end{array}$ & $\begin{array}{l}0,4787(0,0275) \\
0,2454(0,0237) \\
0,2757(0,0246)\end{array}$ & $\begin{array}{l}0,7516(0,0245) \\
0,1354(0,0194) \\
0,1129(0,0180)\end{array}$ \\
\hline Sales turnover & $\begin{array}{c}0 \text { if turnover at most } 1 \text { million } \\
1 \text { if turnover between } 1 \text { and } 5 \text { million } \\
2 \text { if turnover at least } 5 \text { million }\end{array}$ & $\begin{array}{l}0,5474(0,0196) \\
0,0808(0,0107) \\
0,3716(0,0190)\end{array}$ & $\begin{array}{l}0,4084(0,0269) \\
0,0960(0,0161) \\
0,4954(0,0274)\end{array}$ & $\begin{array}{l}0,6967(0,0261) \\
0,0645(0,0139) \\
0,2387(0,0242)\end{array}$ \\
\hline Website & $\begin{array}{l}0 \text { if company does has no website } \\
1 \text { if the company has a website }\end{array}$ & $\begin{array}{l}0,7855(0,0172) \\
0,2144(0,0172)\end{array}$ & $\begin{array}{l}0,7012(0,0261) \\
0,2987(0,0261)\end{array}$ & $\begin{array}{l}0,8850(0,0197) \\
0,1149(0,0197)\end{array}$ \\
\hline Source of funding & $\begin{array}{l}0 \text { if internal funding only } \\
1 \text { if external funding }\end{array}$ & $\begin{array}{l}0,2938(0,0181) \\
0,7062(0,0181)\end{array}$ & $\begin{array}{l}0,2134(0,2265) \\
0,7865(0,0226)\end{array}$ & $\begin{array}{l}0,3803(0,0278) \\
0,6196(0,0278)\end{array}$ \\
\hline Competition & $\begin{array}{c}0 \text { if the company has no competitor } \\
1 \text { if the company has at least one } \\
\text { competitor }\end{array}$ & $\begin{array}{l}0,0713(0,0102) \\
0,9286(0,0102)\end{array}$ & $\begin{array}{l}0,0962(0,0164) \\
0,9037(0,0164)\end{array}$ & $\begin{array}{l}0,0453(0,0118) \\
0,9546(0,0118)\end{array}$ \\
\hline
\end{tabular}

Source: authors

Let us consider $U_{i, I}$ utility of the first decision and $U_{i, N}$ utility of the second decision. Then, the decision is made by comparing these two utilities. Let $y_{1, i}^{*}$ the latent variable equal to the difference in utilities:

$y_{1, i}^{*}=U_{i, I}-U_{i, N}$

If the company has innovated on a managerial level then; $y_{1, i}^{*}>0$ if not $y_{1, i}^{*} \leq 0$. In this case, the binary Probit model is used. It should be noted that the Probit regression uses the maximum likelihood method to estimate the model parameters. To achieve the results, the following equations are estimated:

$$
\text { InnovM }_{i}=\beta X_{i}+\mathcal{E}_{i} \quad \text { and } \quad \text { Innov }_{i}=\beta X_{i}^{\prime}+\mathcal{E}_{i}
$$

InnovM represents managerial innovation; $\beta$ represents the vector of the parameters; $\varepsilon$ represents the error term, $\mathrm{X}$ and $\mathrm{X}$ ' represent the vectors of observable characteristics. Among these observable 
characteristics, besides to having on one side the openness variable and on the other side the degree of openness variable, there is also a set of control variables.

Referring to the work of Dubouloz and Bocquet (2013), the absorption capacity, the size of the company and the website can be included in the model. However, according to Cohen and Levinthal (1990), the absorptive capacity allows a company to recognize the value of knowledge from external actors, to assimilate and to apply it. To measure absorptive capacity, this study used the Cohen and Levinthal (1990) approach based on competent specialists, according to which for a company to assimilate complex knowledge from outside, it must have specialized and competent employees in that area of activity. Thus, the authors considered that a company has a high absorption capacity if the manager has a specific qualification for the exercise of his activity, otherwise the company will be considered as having a low absorption capacity. The website is introduced into the model to explain the communication structure between the company and its external environment. To control the unobserved heterogeneity of the company's financial structure, the source of financing is introduced into the model. However, Amore et al. (2013) consider that financial development reflected in the openness of the financial system to transactions is essential for the innovation performance of companies. The need to include the size of the company, its turnover and the state of competition is justified by the generally accepted view that large companies can achieve economies of scale (Titman \& Wessels, 1988) and to be better able to prevent new entrants from operating in the market (Nunes, Serrasqueiro \& Sequeira, 2009) by applying new management practices.

However, simple Probit models remain limited in that they do not take into account the interdependence between openness and managerial innovation on the one hand and openness intensity and managerial innovation on the other. To take this interdependence into account, the recursive bivariate Probit model must be used (Diallo, 2001; Adjiwanou, 2005). This model makes it possible to consider the interdependence between the dependent variable and the variable of interest, and also to consider the possibility that the choice for a company to cooperate with external partners is not random. This choice depends on certain unobserved characteristics. Thus, this model allows us to consider the causality between variables by avoiding endogeneity bias. Consider $y_{1 i}^{*}, y_{2 i}^{*}$ and $y_{3 i}^{*}$ as respectively the latent variable of openness, intensity of openness and managerial innovation respectively. That is:

$$
\begin{aligned}
& \left\{\begin{array}{l}
y_{1 i}^{*}=x_{1 i} \alpha+\gamma \pi+\mathcal{E}_{1 i} \\
y_{3 i}^{*}=x_{3 i} \beta+y_{1 i}^{*} \lambda+\mathcal{E}_{3 i}
\end{array}\right. \\
& \left\{\begin{array}{l}
y_{2 i}^{*}=x_{2 i} \delta+\varnothing \Psi+\mathcal{E}_{2 i} \\
y_{3 i}^{*}=x_{3 i} \beta+y_{2 i}^{*} \lambda+\mathcal{E}_{3 i}
\end{array}\right.
\end{aligned}
$$

The error terms $\varepsilon_{1 i}, \varepsilon_{2 i}$ and $\varepsilon_{3 i}$, are such that with $\operatorname{cov}\left(\varepsilon_{1 i}, \varepsilon_{3 i}\right)=\rho$ and $\operatorname{cov}\left(\varepsilon_{2 i}, \varepsilon_{3 i}\right)=v$ $\rho \neq 0$ and $\quad v \neq 0 . \pi$ refers to all the instrumental variables that are correlated with openness, but may not be correlated with managerial innovation. Similarly, $\psi$ refers to all instrumental variables that are correlated to the intensity of openness, but may not be correlated to managerial innovation. For these two cases, there is among other things digitilisation and market access. Digitisation is an instrumental variable correlated with both openness and managerial innovation and this study assumes that with the advent of the digital economy, a company has a website is more willing to collaborate with other external actors than a company without a website. Market access is an instrumental variable that does not correlate with managerial innovation but correlates with openness. However, this study 
assumes that a company that operates in a sector of activity that does not have free access may lack partners with whom to collaborate, thus limiting openness and the intensity of openness.

The use of all these econometric models leads to several results. The presentation of these results is the objective of the next section.

\section{RESULTS AND DISCUSSION}

The analysis will be based on the results relating to the effect of openness on the one hand and on the results relating to the effect of the degree of openness on the other hand.

\section{The Effect of Openness on Managerial Innovation}

The results related to the openness are presented in Table 2. The first column is related to the binary Probit model while the second and third columns are related to the bivariate Probit model. Concerning the binary Probit model, the authors can notice the fact that when a company opens up to its environment its probability of adopting new managerial practices increases by about $25 \%$. Thus, a company's collaboration with other market players encourages the adoption of managerial innovation. This result had already been found by several other authors (for example: Pfeffer \& Salancik, 1978; Frambach \& Schillewaert, 2002; Laursen \& Salter, 2006; Mol \& Birkinshaw, 2009; Dubouloz, 2012; Dubouloz \& Bocquet, 2013). It could be justified by the fact that companies that collaborate with external actors benefit from additional knowledge that is important for managerial innovation. However, the results of Dubouloz and Bocquet (2013) are nuanced. These authors show that although openness is useful for managerial innovation, its effect can be harmful when external sources become numerous.

Adaptability also plays a significant role in explaining the adoption of managerial innovation. However, compared to low absorption capacity companies, high absorption capacity companies have a 0.10 higher probability of managerial innovation. This would mean that companies that recognize the value of knowledge from external actors, and that assimilate and apply it, are more likely to introduce new managerial practices than their counterparts with low absorption capacity. This result is consistent with those of Dubouloz and Bocquet (2013) and Huang and Rice (2012). For example, Huang and Rice (2012) show that absorptive capacity (measured by human capital) and organizational innovation (measured by the display of new organizational processes) change in the same direction.

The company's turnover also plays a significant role in explaining the adoption of managerial innovation. However, if one compares a company with a turnover of at most one million CFA francs to one with a turnover of between one million and five million CFA francs and also another with a turnover of at least five million CFA francs, then the probability of managerial innovation increases by 0.24 and 0.25 respectively. So, the authors can say that as the company's turnover increases, so does the probability that the company will innovate management wise. This result is consistent with that of Damanpour (1987) and Ganter and Hecker (2013). To these authors, for a company to see its turnover increase, it would have to apply innovative organizational methods to deal with the coordination problems that arise. In this light, companies with a high turnover are those that have applied new managerial practices (Damanpour, 1996). Similarly, companies with high turnover (large companies) also generally have a greater pool of knowledge, skills and other resources to successfully introduce new organizational practices (Ganter \& Hecker, 2013).

The adoption of managerial innovation is also significantly influenced by the ownership of a website. However, companies with a website have a 0.11 higher probability of adopting a managerial innovation as compared to their counterparts without a website. This result shows the effect of digital transformation on the innovative capacity of companies. In this regard, Bharadwaj (2000) shows that companies that make significant investments in information and communication technologies achieve higher levels of innovation than other companies. In fact, ideas that become innovations are usually implemented through information and communication technology initiatives. However, 
reduced transaction costs, improved business processes, better coordination with suppliers and increased diversification resulting from the use of information and communication technologies lead to efficiency gains that in turn will facilitate innovation (Koellinger, 2005).

The source of financing also significantly influences the introduction of managerial innovation. However, when the authors observe the sign of the marginal effect associated with this variable, they can affirm that the probability of managerial innovation increases by $13 \%$ for a company using external financing compared to a company using only internal financing. Thus, the financial openness of a company has a positive effect on the adoption of managerial innovation. This result is consistent with other empirical studies, although not directly focusing on managerial innovation. However, by basing its analysis on the degree of use of external financing, Ayyagari et al. (2011) shows that access to external financing facilitates innovation. Moreover, Herrera et al. (2007) base their analysis on the duration of the business-bank relationship and show that sustainable businessbanking relationships encourage the introduction of innovation activities. However, other studies such as Canepa and Stoneman (2005) have found a positive effect of the availability of internal financing on innovation activities.

Competition also plays a significant role in explaining managerial innovation. However, compared to companies in a monopoly situation, companies in a competitive situation are less likely (by 17\%)

Table 2. Effect of openness on managerial innovation

\begin{tabular}{|c|c|c|c|}
\hline & Binary probit & \multicolumn{2}{|c|}{ Recursive bivariate probit } \\
\hline Variables & Managerial innovation & Managerial innovation & Openness \\
\hline $\begin{array}{l}\text { Openness } \\
\text { No openness } \\
\text { Openness }\end{array}$ & $\begin{array}{c}\operatorname{Ref} \\
0,2546(0,0524) * * *\end{array}$ & $\begin{array}{c}\text { Ref } \\
0,3742 * * *\end{array}$ & \\
\hline $\begin{array}{c}\text { Absorption capacity } \\
\text { Low } \\
\text { high }\end{array}$ & $\begin{array}{c}\text { Ref } \\
0,1013(0,0402)^{* *}\end{array}$ & $\begin{array}{c}\text { Ref } \\
0,1052 * *\end{array}$ & \\
\hline $\begin{array}{l}\text { Size of the company } \\
\text { Very small } \\
\text { Small and medium size } \\
\text { Large }\end{array}$ & $\begin{array}{c}\text { Ref } \\
-0,0784(0,0892) \\
-0,0912(0,0965)\end{array}$ & $\begin{array}{c}\text { Ref } \\
-0,0979 \\
-0,1220\end{array}$ & \\
\hline $\begin{array}{c}\text { Sales turnover } \\
\text { At most } 1 \text { million } \\
\text { Between } 1 \text { and } 5 \text { million } \\
\text { More than } 5 \text { million }\end{array}$ & $\begin{array}{c}\text { Ref } \\
0,2426(0,1064)^{* *} \\
0,2599(0,0964)^{* * *}\end{array}$ & $\begin{array}{c}\text { Ref } \\
0,2580^{* *} \\
0,2563 * *\end{array}$ & \\
\hline $\begin{array}{c}\text { Website } \\
\text { no website } \\
\text { has a website }\end{array}$ & $\begin{array}{c}\text { Ref } \\
0,1131(0,0668)^{*}\end{array}$ & $\begin{array}{c}\text { Ref } \\
0,1184\end{array}$ & $\begin{array}{c}\text { Ref } \\
0,2212(0,0524)^{* * *}\end{array}$ \\
\hline $\begin{array}{l}\text { Source of funding } \\
\text { internal only } \\
\text { external }\end{array}$ & $\begin{array}{c}\operatorname{Ref} \\
0,1326(0,0420) * * *\end{array}$ & $\begin{array}{c}\text { Ref } \\
0,1508^{* * *}\end{array}$ & \\
\hline $\begin{array}{c}\text { Competition } \\
\text { no competitor } \\
\text { has at least a competitor }\end{array}$ & $\begin{array}{c}\text { Ref } \\
-0,1715(0,0913)^{*}\end{array}$ & $\begin{array}{c}\text { Ref } \\
-0,1900 *\end{array}$ & \\
\hline \multirow[t]{2}{*}{$\begin{array}{l}\text { Market Access } \\
\text { free access } \\
\text { restricted access }\end{array}$} & & & $\begin{array}{c}\operatorname{Ref} \\
-0,0935(0,0422)^{* *}\end{array}$ \\
\hline & $\begin{array}{c}\text { Prob }>\text { chi } 2=0,0000 \\
\text { Pseudo R2 }=0,1399\end{array}$ & \multicolumn{2}{|c|}{$\begin{array}{c}\text { Athrho }-0,2161(0,6519) \\
\text { Prob }>\text { chi2 } 0,0000\end{array}$} \\
\hline
\end{tabular}

Source: Author's estimate. $\left(^{* \star *}\right),\left({ }^{* \star}\right)$ and $\left({ }^{\star}\right)$ represent the significance at $1 \%, 5 \%$ and $10 \%$ respectively 
to adopt new managerial practices. In this light, the authors can say that a company in a monopoly situation easily adopts new managerial practices than companies with competitors. This result could be justified by the argument that, when a company operates in a monopoly situation, it is motivated to develop strategies to prevent potential competitors from entering the market, and hence the adoption of new managerial practices.

However, a company's ability to collaborate with other companies or organizations depends on several unobservable factors that can have an effect on the adoption of managerial innovation. In this way, market access and the website can influence the choice of the company to cooperate. Therefore, this study considers that with digitisation, a company that has a website is more likely to cooperate with other organisations. Similarly, this article considers that when access to a market is not free, a company is obliged to cooperate with a foreign partner in order to enter the market. In this case, the omission of these variables can lead to a biased estimator. To solve this problem we used the bivariate probit model.

The bivariate Probit results show that the website variable and the market access variable are strong instruments. They explain at least $5 \%$ of a company's choice to collaborate with external partners. Using the bivariate Probit model, the authors can notice that when a company opens up to its environment, its probability of adopting new managerial practices increases by about $0.37 \%$. Thus, even by correcting the endogeneity bias, openness always has a positive and significant impact on the managerial innovation of Cameroonian companies. The authors can also see that the openness effect is higher in the bivariate Probit model than in the binary probit model. Thus, ignoring instrumental variables reduced the effect of openness. Regarding the control variables, their results are not significantly different from those obtained in the simple Probit model.

\section{The Effect of The Degree of Openness on Managerial Innovation}

The results for the degree of openness are presented in Table 3. The authors can see that even if the model is globally significant at the $1 \%$ threshold (Prob $>$ chi $2=0.006$ ) and explains nearly $20 \%$ of the variability in the degree of openness with respect to managerial innovation (Pseudo R2 $=0.2006$ ), only the variable relating to the openness intensity significantly explains the dependent variable. Thus, the probability for companies that cooperate with only companies of the same group to innovate in terms of management is reduced by 0.27 compared to companies that cooperate at least with companies of the other groups. However, a company introduces more new managerial practices when it cooperates with at least one company from another group. This result seems a little bit logical insofar as when a company cooperates with only the organizations of the same group, it can easily innovate on a managerial level following the phenomenon of mimicry. However, when the same company cooperates with at least one company from a different group, then the probability of her managerial innovation becomes even greater because it can not only imitate what is done elsewhere but is also a victim of several pressures from external partners.

The results of the bivariate Probit show that only the website significantly explains the intensity of openness. It is therefore considered as a strong instrument. The authors can notice for this model that the probability for a company that cooperates with at least one company from a different group to innovates in terms of management increases by 0.30 as compared to companies that only cooperate with companies of the same group. By correcting the endogeneity bias, a company's collaboration with other companies from other group always has a positive and significant impact on the managerial innovation of Cameroonian companies. As before, this study also finds that the effect of the openness intensity is higher in the bivariate probit model than in the binary Probit model. Thus, ignoring instrumental variables reduced the effect of openness intensity. As for the control variables, their results are not significantly different from those obtained in the simple Probit model. 
Table 3. Effect of openness intensity on managerial innovation

\begin{tabular}{|c|c|c|c|}
\hline \multirow[t]{2}{*}{ Variables } & \multirow{2}{*}{$\frac{\text { Binary probit }}{\text { Managerial innovation }}$} & \multicolumn{2}{|c|}{ Recursive bivariate probit } \\
\hline & & Managerial innovation & Openness intensity \\
\hline $\begin{array}{c}\text { Openness intensity } \\
\text { Companies of same group } \\
\text { Other companies }\end{array}$ & $\begin{array}{c}\text { Ref } \\
0,2775(0,1083)^{* * *}\end{array}$ & $\begin{array}{c}\text { Ref } \\
0,3004 * *\end{array}$ & \\
\hline $\begin{array}{c}\text { Absorption capacity } \\
\text { Low } \\
\text { High }\end{array}$ & $\begin{array}{c}\text { Ref } \\
-0,0663(0,1030)\end{array}$ & $\begin{array}{c}\text { Ref } \\
-0,0779\end{array}$ & \\
\hline $\begin{array}{l}\text { Size of the company } \\
\text { Very small } \\
\text { Small and medium size } \\
\text { Large }\end{array}$ & $\begin{array}{c}\text { Ref } \\
0,1274(0,1678) \\
0,0040(0,2208)\end{array}$ & $\begin{array}{c}\text { Ref } \\
0,1205 \\
0,0022\end{array}$ & \\
\hline $\begin{array}{c}\text { Sales turnover } \\
\text { At most } 1 \text { million } \\
\text { Between 1and } 5 \text { million } \\
\text { More than } 5 \text { million }\end{array}$ & $\begin{array}{c}\text { Ref } \\
0,0685(0,1990) \\
0,1250(0,2163)\end{array}$ & $\begin{array}{c}\text { Ref } \\
0,0603 \\
0,1241\end{array}$ & \\
\hline $\begin{array}{c}\text { Website } \\
\text { no website } \\
\text { has a website }\end{array}$ & $\begin{array}{c}\text { Ref } \\
0,0678(0,1030)\end{array}$ & $\begin{array}{c}\text { Ref } \\
0,0371\end{array}$ & $\begin{array}{c}\text { Ref } \\
0,1720(0,090)^{*}\end{array}$ \\
\hline $\begin{array}{l}\text { Source of funding } \\
\text { internal only } \\
\text { external }\end{array}$ & $\begin{array}{c}\text { Ref } \\
0,0473(0,0767)\end{array}$ & $\begin{array}{c}\text { Ref } \\
0,0364\end{array}$ & \\
\hline $\begin{array}{c}\text { Competition } \\
\text { no competitor } \\
\text { has at least a competitor }\end{array}$ & $\begin{array}{c}\text { Ref } \\
-0,1220(0,1209)\end{array}$ & $\begin{array}{c}\text { Ref } \\
-0,1070\end{array}$ & \\
\hline \multirow[t]{2}{*}{$\begin{array}{l}\text { Market Access } \\
\text { free access } \\
\text { restricted access }\end{array}$} & & & $\begin{array}{c}\text { Ref } \\
0,0254(0,0865)\end{array}$ \\
\hline & $\begin{array}{c}\text { Prob }>\text { chi } 2=0,0067 \\
\text { Pseudo } R 2=0,2006\end{array}$ & \multicolumn{2}{|c|}{$\begin{array}{l}\text { Athrho }-0,5538(1,1155) \\
\text { Prob >chi2 0,0001 }\end{array}$} \\
\hline
\end{tabular}

Source: Author's estimate. $\left({ }^{* * *}\right),\left({ }^{* *}\right)$ and $\left(^{*}\right)$ represent the significance at $1 \%, 5 \%$ and $10 \%$ respectively

\section{CONCLUSION}

In revisiting the literature, this study found that the previous works used three channels to establish a relationship between openness and managerial innovation: the external pressure channel, the mimicry channel and the knowledge used channel. To verify this in the Cameroonian context, this study used data from the Centre de Recherche en Economie et Gestion (CEREG) of the University of Yaoundé II. Using the Binary Probit and Recursive Bivariate Probit models, the authors found that openness plays a significant role in the adoption of managerial innovation by Cameroonian firms. Particularly, the authors found that when a company collaborates with other companies or organizations (other companies in the same group, suppliers, customers, customers, companies in the same sector, companies in other sectors, consultants, commercial laboratories, higher education institutions, other research and development organizations) then its probability of adopting new managerial practices increases by 0.37 as compared to private companies. They also found that when a company collaborates with companies in other groups, its probability of adopting new managerial practices increases by 0.30 when compared to a company that only collaborates with companies of the same group. 
This study therefore recommends that Cameroonian business leaders orient their policies towards openness through cooperation with all market players, which will undoubtedly contribute to the induction of managerial innovation.

\section{LIMITATIONS AND FUTURE PERSPECTIVES}

As mentioned in the methodology, the data used in this study were obtained from 643 companies surveyed in three main cities of the country (Yaoundé, Douala, and Bafoussam). The main limitation of this study is therefore the non-representativeness of the sample. As a research perspective, the authors plan to conduct a similar study with a more representative sample. 


\section{REFERENCES}

Abrahamson, E. (1991). Managerial fads and fashions: The diffusion and rejection of innovations. Academy of Management Review, 16(3), 586-612. doi:10.5465/amr.1991.4279484

Adjiwanou, V. (2005). Impact de la pauvreté sur la scolarisation et le travail des enfants de 6-14 ans au Togo. Unité de Recherche Démographique (URD), Université de Lomé, Togo.

Amore, M. D., Schneider, C., \& Žaldokas, A. (2013). Credit supply and corporate innovation. Journal of Financial Economics, 109(3), 835-855. doi:10.1016/j.jfineco.2013.04.006

Audretsch, D. B., \& Feldman, M. P. (1996). R\&D spillovers and the geography of innovation and production. The American Economic Review, 86(3), 630-640.

Ayyagari, M., Demirgüç-Kunt, A., \& Maksimovic, V. (2011). Firm innovation in emerging markets: The role of finance, governance, and competition. Journal of Financial and Quantitative Analysis, 46(6), 1545-1580. doi:10.1017/S0022109011000378

Bharadwaj, A. S. (2000). A resource-based perspective on information technology capability and firm performance: An empirical investigation. Management Information Systems Quarterly, 24(1), 169-196. doi:10.2307/3250983

Biatour, B., \& Kegels, C. (2008). Les déterminants de l'innovation dans une petite économie ouverte: le cas de la Belgique. Bureau federal du Plan (Belgian Federal Planning Bureau), Working Paper, 11-08.

Bocquet, R., \& Dubouloz, S. (2020). Firm Openness and Managerial Innovation : Rebalancing Deliberate Actions and Institutional Pressures. Journal of Innovation Economics Management.

Bogers, M., Chesbrough, H., \& Moedas, C. (2018). Open innovation : Research, practices, and policies. California Management Review, 60(2), 5-16. doi:10.1177/0008125617745086

Borgatti, S. P., \& Cross, R. (2003). A relational view of information seeking and learning in social networks. Management Science, 49(4), 432-445. doi:10.1287/mnsc.49.4.432.14428

Canepa, A., \& Stoneman, P. (2005). Financing constraints in the inter firm diffusion of new process technologies. Essays in Honor of Edwin Mansfield, 247-257.

Cheng, L., Lyu, Y., Su, J., \& Han, S. (2019). Inbound openness and its impact on innovation performance : An agent-based and simulation approach. $R \& D$ Management, 1-13.

Chesbrough, H. W. (2006). The era of open innovation. Managing Innovation and Change, 127(3), 34-41.

Clausen, T. H. (2013). External knowledge sourcing from innovation cooperation and the role of absorptive capacity: Empirical evidence from Norway and Sweden. Technology Analysis and Strategic Management, 25(1), 57-70. doi:10.1080/09537325.2012.751009

Cohen, W. M., \& Levinthal, D. A. (1990). Absorptive capacity: A new perspective on learning and innovation. Administrative Science Quarterly, 35(1), 128-152. doi:10.2307/2393553

D'Ambrosio, A., Gabriele, R., Schiavone, F., \& Villasalero, M. (2017). The role of openness in explaining innovation performance in a regional context. The Journal of Technology Transfer, 42(2), 389-408. doi:10.1007/ s10961-016-9501-8

Damanpour, F. (1987). The adoption of technological, administrative, and ancillary innovations: Impact of organizational factors. Journal of Management, 13(4), 675-688. doi:10.1177/014920638701300408

Damanpour, F. (1996). Organizational complexity and innovation: Developing and testing multiple contingency models. Management Science, 42(5), 693-716. doi:10.1287/mnsc.42.5.693

Damanpour, F., \& Aravind, D. (2012). Managerial innovation: Conceptions, processes and antecedents. Management and Organization Review, 8(2), 423-454. doi:10.1111/j.1740-8784.2011.00233.x

Damanpour, F., Sanchez-Henriquez, F., \& Chiu, H. H. (2018). Internal and external sources and the adoption of innovations in organizations. British Journal of Management, 29(4), 712-730. doi:10.1111/1467-8551.12296 
Dekkers, R., Koukou, M. I., Mitchell, S., \& Sinclair, S. (2019). Engaging with open innovation : A scottish perspective on its opportunities, challenges and risks. Journal of Innovation Economics Management, 1(1), 193-226. doi:10.3917/jie.028.0187

Di Nauta, P., Merola, B., Caputo, F., \& Evangelista, F. (2018). Reflections on the role of university to face the challenges of knowledge society for the local economic development. Journal of the Knowledge Economy, 9(1), 180-198. doi:10.1007/s13132-015-0333-9

Diallo, Y. (2001). Les déterminants du travail des enfants en Côte d'Ivoire. Groupe d'Economie du Développement de l'Université Montesquieu Bordeaux IV.

Dimaggio, P. J., \& Powell, W. W. (1983). The iron cage revisited: Institutional isomorphism and collective rationality in organizational fields. American Sociological Review, 48(2), 147-160. doi:10.2307/2095101

Dubouloz, S. (2012). Organizational innovation: clarifying the concept as output and as process and suggesting research avenues from these two angles of analysis. Association Internationale de Managment Strategique.

Dubouloz, S., \& Bocquet, R. (2013). Innovation organisationnelle. Revue française de gestion, (6), 129-147.

Escribano, A., Fosfuri, A., \& Tribó, J. A. (2009). Managing external knowledge flows: The moderating role of absorptive capacity. Research Policy, 38(1), 96-105. doi:10.1016/j.respol.2008.10.022

Evan, W. M. (1966). Organizational lag. Human Organization, 25(1), 51-53. doi:10.17730/ humo.25.1.v7354t3822136580

Fagerberg, J. (1987). A technology gap approach to why growth rates differ. Research Policy, 16(2-4), 87-99. doi:10.1016/0048-7333(87)90025-4

Fantino, D., Mori, A., \& Scalise, D. (2015). Collaboration between firms and universities in Italy : The role of a firm's proximity to top-rated departments. Italian Economic Journal, 1(2), 219-251. doi:10.1007/s40797014-0003-2

Fey, C. F., \& Birkinshaw, J. (2005). External sources of knowledge, governance mode, and R\&D performance. Journal of Management, 31(4), 597-621. doi:10.1177/0149206304272346

Frambach, R. T., \& Schillewaert, N. (2002). Organizational innovation adoption: A multi-level framework of determinants and opportunities for future research. Journal of Business Research, 55(2), 163-176. doi:10.1016/ S0148-2963(00)00152-1

Ganter, A., \& Hecker, A. (2013). Deciphering antecedents of organizational innovation. Journal of Business Research, 66(5), 575-584. doi:10.1016/j.jbusres.2012.02.040

Ghisetti, C. (2018). On the economic returns of eco-innovation: where do we stand? dans new developments in eco-innovation research. Springer.

Hamel, G. (2006). The why, what, and how of management innovation. Harvard Business Review, 84(2), 72. PMID:16485806

Herrera, A. M., \& Minetti, R. (2007). Informed finance and technological change: Evidence from credit relationships. Journal of Financial Economics, 83(1), 223-269. doi:10.1016/j.jfineco.2005.12.001

Hinteregger, C., Durst, S., Temel, S., \& Yesilay, R. B. (2019). The impact of openness on innovation in SMEs. International Journal of Innovation Management, 23(01), 1950003. doi:10.1142/S1363919619500038

Huang, F., \& Rice, J. (2012). Openness in product and process innovation. International Journal of Innovation Management, 16(04), 1250020. doi:10.1142/S1363919612003812

Huggins, R., Prokop, D., \& Thompson, P. (2019). Universities and open innovation : The determinants of network centrality. The Journal of Technology Transfer, 1-40. doi:10.1007/s10961-019-09720-5

Johnston, A., \& Huggins, R. (2017). University-industry links and the determinants of their spatial scope : A study of the knowledge intensive business services sector. Papers in Regional Science, 96(2), 247-260. doi:10.1111/pirs.12185

Koellinger, P. (2005). Why IT matters: An empirical study of e-business usage, innovation, and firm performance. DIW Discussion Papers. 
Koput, K. W. (1997). A chaotic model of innovative search: Some answers, many questions. Organization Science, 8(5), 528-542. doi:10.1287/orsc.8.5.528

Kostopoulos, K., Papalexandris, A., Papachroni, M., \& Ioannou, G. (2011). Absorptive capacity, innovation, and financial performance. Journal of Business Research, 64(12), 1335-1343. doi:10.1016/j.jbusres.2010.12.005

Laursen, K., \& Salter, A. (2006). Open for innovation: The role of openness in explaining innovation performance among UK manufacturing firms. Strategic Management Journal, 27(2), 131-150. doi:10.1002/smj.507

Le Roy, F., Robert, M., \& Giuliani, P. (2013). L'innovation managériale. Revue française de gestion, (6), 77-90.

Lisowska, R., \& Stanisławski, R. (2015). The cooperation of small and medium-sized enterprises with business institutions in the context of open innovation. Procedia Economics and Finance, 23, 1273-1278. doi:10.1016/ S2212-5671(15)00509-2

Ma, X., Yao, X., \& Xi, Y. (2006). Business group affiliation and firm performance in a transition economy : A focus on ownership voids. Asia Pacific Journal of Management, 23(4), 467-483. doi:10.1007/s10490-006-9011-6

Mol, M. J., \& Birkinshaw, J. (2009). The sources of management innovation: When firms introduce new management practices. Journal of Business Research, 62(12), 1269-1280. doi:10.1016/j.jbusres.2009.01.001

Mongo, M. (2013). Les déterminants de l'innovation: Une analyse comparative service/industrie à partir des formes d'innovation développées. Revue d'Economie Industrielle, (143), 71-108. doi:10.4000/rei.5632

Montalvan-Burbano, N., Plaza-Ubeda, J. A., Perez-Valls, M., \& Sabando-Vera, D. (2019). Dataset on organizational innovation and its determinants in the SMEs hotels. Data in Brief, 26, 104352. doi:10.1016/j. dib.2019.104352 PMID:31508465

Nunes, P. J. M., Serrasqueiro, Z. M., \& Sequeira, T. N. (2009). Profitability in Portuguese service industries: A panel data approach. Service Industries Journal, 29(5), 693-707. doi:10.1080/02642060902720188

Ozgen, C., Nijkamp, P., \& Poot, J. (2013). The impact of cultural diversity on firm innovation: Evidence from Dutch micro-data. IZA Journal of Migration, 2(1), 18. doi:10.1186/2193-9039-2-18

Partha, D., \& David, P. A. (1994). Toward a new economics of science. Research Policy, $23(5), 487-521$. doi:10.1016/0048-7333(94)01002-1

Partha, D., \& David, P. A. (1994). Toward a new economics of science. Research Policy, $23(5), 487-521$. doi:10.1016/0048-7333(94)01002-1

Pfeffer, J., \& Salancik, G. R. (1978). The extemal control of organizations. A Resource Dependence Perspective. Harper \& Row.

Radnejad, A. B., \& Vredenburg, H. (2017). Dsruptive Technological Process Innovation Capability in a Process-oriented Industry. Academy of Management Proceedings, 2017(1), 11616. doi:10.5465/ AMBPP.2017.11616abstract

Rojas, M. G. A., Solis, E. R. R., \& Zhu, J. J. (2018). Innovation and network multiplexity : R\&D and the concurrent effects of two collaboration networks in an emerging economy. Research Policy, 47(6), 1111-1124. doi:10.1016/j.respol.2018.03.018

Shen, Z., Siraj, A., Jiang, H., Zhu, Y., \& Li, J. (2020). Chinese-Style Innovation and Its International Repercussions in the New Economic Times. Sustainability, 12(5), 1859. doi:10.3390/su12051859

Sieg, J. H., Wallin, M. W., \& Von Krogh, G. (2010). Managerial challenges in open innovation: A study of innovation intermediation in the chemical industry. Research Management, 40(3), 281-291.

Sun, Y., \& Cao, C. (2018). The evolving relations between government agencies of innovation policymaking in emerging economies: A policy network approach and its application to the Chinese case. Research Policy, 47(3), 592-605. doi:10.1016/j.respol.2018.01.003

Tang, M., Xu, P., Llerena, P., \& Afshar Jahanshahi, A. (2019). The impact of the openness of firms' external search strategies on exploratory innovation and exploitative innovation. Sustainability, 11(18), 4858. doi:10.3390/ su11184858 
Teece, D. J. (1980). Economies of scope and the scope of the enterprise. Journal of Economic Behavior \& Organization, 1(3), 223-247. doi:10.1016/0167-2681(80)90002-5

Terjesen, S., \& Patel, P. C. (2017). In search of process innovations : The role of search depth, search breadth, and the industry environment. Journal of Management, 43(5), 1421-1446. doi:10.1177/0149206315575710

Tether, B. S. (2002). Who co-operates for innovation, and why: An empirical analysis. Research Policy, 31(6), 947-967. doi:10.1016/S0048-7333(01)00172-X

Titman, S., \& Wessels, R. (1988). The determinants of capital structure choice. The Journal of Finance, 43(1), 1-19. doi:10.1111/j.1540-6261.1988.tb02585.x

Wang, D., \& Chen, S. (2013). Does intellectual capital matter? High-performance work systems and bilateral innovative capabilities. International Journal of Manpower, 34(8), 861-879. doi:10.1108/IJM-07-2013-0167

Ziadlou, D. (2020). Managerial Innovation for Digital Healthcare Transformation. In Leadership, Management, and Adoption Techniques for Digital Service Innovation (p. 141-161). IGI Global. doi:10.4018/978-1-79982799-3.ch008

Zobel, A.-K., Lokshin, B., \& Hagedoorn, J. (2017). Formal and informal appropriation mechanisms : The role of openness and innovativeness. Technovation, 59, 44-54. doi:10.1016/j.technovation.2016.10.001

Joël Stephan Tagne is PhD in Economics at the University of Dschang (Cameroon). He is currently a researcher at the Research Laboratory in Basic and Applied Economics (LAREFA) and is also a member of the Council for the Development of Social Science Research in Africa (CODESRIA). His fields of specialization are entrepreneurship, innovation, gender, microcredit, digital economy, informal economy and cultural economy. He has a number of scientific works to his credit, mainly a publication in the African management journal on "University curricula and youth entrepreneurship in Cameroon" in 2017. He also participated in international scientific conferences, most recently held in Dakar (Senegal) from 17 to 28 June 2019 on the theme "Women, informal economies and the financialization of microcredit in Africa." 